\title{
A CENA PERTURBADA: PERSONAGENS DRAMÁTICAS FEMININAS DE GERVÁSIO LOBATO E GUIOMAR TORRESÃO
}

Claudia Barbieri Masseran ${ }^{1}$

Resumo: $\mathrm{O}$ artigo recupera três personagens dramáticas femininas pertencentes a duas peças originais: D. Leonor Gonçalves da comédia em um ato $A$ burguesa, da pena de Gervásio Lobato (1850-1895), de 1882 e D. Christiana e D. Gabriela de Educaşão Moderna, comédia em três atos, escrita por Guiomar Torresão em 1891. Para tanto, faz-se necessária uma breve incursão na história da educação feminina em Portugal no século XIX e o entendimento do papel reservado às mulheres na sociedade coeva.

Palavras-chave: personagem dramática feminina; Gervásio Lobato; Guiomar Torresão; educação feminina.

\section{THE DISTURBED SCENE: FEMALE DRAMATIC CHARACTERS OF GERVÁSIO LOBATO AND GUIOMAR TORRESÃO}

\begin{abstract}
The article retrieves three female dramatic characters belonging to two original pieces: $\mathrm{D}$. Leonor Gonçalves of the comedy in an act The bourgeois, from the nib of Gervásio Lobato (18501895), of 1882 and D. Christiana and D. Gabriela of Modern Education, comedy in three acts, written by Guiomar Torresão in 1891. In order to do so, a brief incursion into the history of female education in Portugal in the nineteenth century is necessary, and the understanding of the role reserved to women in society should be considered.
\end{abstract}

Keywords: female dramatic character; Gervásio Lobato; Guiomar Torresão; female education.

Perguntaram a Jacyntho Benavente se já tinha reparado na quantidade de mulheres que, ultimamente, se dedicavam à literatura.

- Sim - respondeu o grande dramaturgo espanhol - e considero isso um fenômeno muito lamentável. Aumenta-se o número de maus livros e... diminui-se o de mulheres.

(Correio Paulistano, de 9 de julho de 1935, no 24.323, p. 11)

Sobre a literatura de autoria feminina incide, genericamente, três críticas. A primeira, definida de forma precisa por Chatarina Edfeldt é o de ser "meramente feita por, para e sobre as mulheres" (EDFELDT, 2006, p. 27). A segunda acusa a escrita feminina por suas supostas faltas: a superficialidade em detrimento do conteúdo grave e reflexivo, a objetividade incipiente, ausência de preocupações estéticas e formais no processo de composição, textos facilmente datáveis e, portanto, pouco significativos para a posteridade, restritos aos leitores de sua época de produção. A terceira, ao contrário, acusa a literatura

\footnotetext{
${ }^{1}$ Doutora em Estudos Literários, pós-doutoranda na Faculdade de Ciências e Letras, UNESP, campus de Araraquara. (Bolsista FAPESP, processo 2014/12592-2)
} 


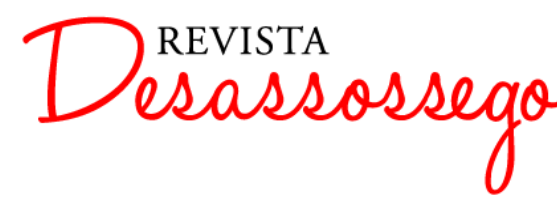

DESASSOSSEGO 17 | JUN/2017 | ISSN 2175-3180

DOI: http://dx.doi.org/10.11606/issn.2175-3180.v9i17p102-127

feminina por aquilo que the sobra: o excesso de lirismo, de sentimentalismo, de discursos moralistas, personagens rasas e arquetípicas.

No universo português oitocentista, tais críticas aparecem invariavelmente nos discursos oficiais que procuram reafirmar e definir os lugares e os papeis das mulheres na sociedade coeva. Todavia, ainda que tímidas e pontuais, há contestações desses lugares comuns feitas por alguns escritores. Este artigo procura recuperar algumas personagens femininas do teatro português que, quando em cena, questionaram por meio de falas e atitudes a subserviência esperada por parte da mulher e, mais admirável, o seu destino. As três personagens principais de que iremos tratar são D. Leonor Gonçalves, da comédia em um ato $A$ Burguesa, de 1882, de Gervásio Lobato (1850-1895) e D. Christiana e Gabriela, da comédia em três atos Educação Moderna, de 1891, de Guiomar Torresão (1844-1898).

\section{A educação feminina no século XIX}

Observai a sociedade em seu estado de decadência; e vereis nos países em que a civilização degenerou já em dissolução e se corrompeu - [...] a mulher deixa de ser mãe, para o que a natureza a formou; é erudita, é autora, é estadista, é tudo menos mulher: com todos os vícios do nosso, não tem nenhuma das virtudes do seu sexo (GARRETT, 1829, p. 194).

Almeida Garrett (1799-1854), em 1829, publicava em Londres o primeiro livro da pretendida série Da educaşão, que abordava a educação doméstica ou paternal, comum a ambos os sexos. Outros três livros completariam o primeiro, mas nunca vieram a lume. $\mathrm{Na}$ sequência abordariam: II - Educação do ginásio, dita pública, para o sexo masculino; III Educação maternal ou do gineceu para o sexo feminino; IV - Educação pública propriamente dita, subdividida em quatro diferentes grupos (órfãos e desamparados, privilegiados, classes inferiores e educação acadêmica e profissional) (GARRETT, 1829, p. XXV-XXVI).

$\mathrm{Na}$ abertura do volume, dirigindo-se ao leitor, Garrett explana sobre o seu método e o sistema escolhido para a composição do livro. Explica que optou pela forma epistolar, por julgá-la mais apta para a proposta pedagógica que se seguia e que as cartas seriam dirigidas à "uma Senhora ilustre encarregada da educação de uma jovem Soberana". Deixa claro que o livro não era um tratado sobre a educação exclusiva de príncipes, antes um tratado de educação em geral (GARRETT', 1829, p. i-ii). Contudo, apesar do primeiro livro 
tratar do que seria a educação comum a ambos os sexos, logo as diferenças aparecem e são reafirmadas. Assim, na nona carta encontramos:

O educando que não tem a desgraça de ser órfão não tem - ou não deve ter ainda outro mentor senão a mãe querida e ciosa, que só a abdicará o natural império de sua tutela quando no vigor da adolescência for necessário separar, da donzelinha que deve ficar no seio materno e sob a vigilância daqueles olhos que nenhuns olhos suprem, o moço forte e robusto que deve ir endurecer de coração e corpo, e desembaraçar de espírito e cabeça para companhia de homens, para a educação do colégio e da escola pública (GARRETT, 1829, p. 199).

Para o autor, esta seria a principal diferença entre a educação de ambos os sexos: a masculina deveria ser pública e em comum e a feminina, por sua vez, impreterivelmente privada e doméstica. Com laivos românticos Garrett pinta, diante dos olhos dos leitores, vislumbres do porvir dos filhos:

[No filho] já vê, com orgulho de mãe, o futuro amparo de seu pai velho, o protetor de sua irmã órfã, o pai de família vigilante e trabalhador, o cidadão zeloso e ativo, o soldado forte e endurecido a trabalhos e privações. [Na filha] já descobre, com vaidade e complacência de mãe e educadora, a íntima amiga de seu peito, a donzela prendada e honesta, objeto disputado pelo honrado galanteio da mais nobre juventude, a esposa feliz e adorada, a mãe carinhosa e querida, a matrona respeitada, enfim, e citada como exemplar e modelo por mães e filhas (GARRET'T, 1829, p. 200-201).

Não há espaço para dúvidas quanto ao ideal feminino a ser atingido pelas mulheres neste contexto histórico. Seu meio: o lar. Seu fito: o casamento. Seu destino: a maternidade. Sua dedicação: a família. Tais concepções não eram apenas propagadas nos mais variados discursos, fossem eles religiosos ou científicos, mas eram respaldadas por práticas sociais correntes, cunhando, de forma quase indelével no imaginário coletivo, a ordem identitária dos gêneros.

Com efeito, a mulher não foi criada para fazer meia e arrumar baús, como se dizia no tempo de nossos bisavós, mas também não nasceu para frequentar a palestra, o foro ou a tribuna. Não que a mulher deva servir ao homem: o termo nem é galante, nem polido nem justo. Mas que a mulher deve estar em certa sujeição ao homem porque depende dele. Não porque a mulher seja fraca: mas porque a sociedade, para a qual nos criou a natureza e fora da qual não podemos viver, exige uma atividade $\mathrm{e}$ quantidade de serviços com que a mulher não pode porque essencialmente foi moldada pela natureza para mãe (GARRETT', 1829, p. 192-193). 
Em meados do século XIX, o acesso à educação para as meninas era restrito. Joel Serrão aponta que em 1845, o número das escolas públicas do continente era de 1116, divididas em 1075 para o sexo masculino e 41 para o feminino (SERRÃO, 1981, p. 31). Dados dos censos de 1878 e 1890 mostram números significativos para as taxas de analfabetismo. Em 1878, a taxa total de analfabetos era de 82,2\%, sendo 46,7\% mulheres e 35,5\% homens. Em 1890 a taxa total diminui para 79,2\%, sendo 44,3\% mulheres e 34,9\% homens ${ }^{2}$.

As famílias que possuíam condições financeiras suficientes garantiam a instrução privada das meninas, contratando, ocasionalmente, após a segunda metade do século XIX, mestres para outras habilidades, como a música, a dança e a pintura. Outra possibilidade era encaminhar as filhas para os colégios particulares religiosos ligados aos Conventos, como, por exemplo, os das irmãs Ursulinas ou Visitandinas, em regime aberto ou de internato, prática corrente desde o século XVIII (SERRÃO, 1981, p. 25). O ensino primário era de três anos e somente em 1888, o Governo foi autorizado pelo Parlamento a criar escolas femininas de ensino secundário, entretanto a lei seria regulamentada dois anos depois.

Até 1870, as meninas aprendiam pouco mais do que ler, escrever e contar (somar, subtrair, multiplicar e dividir). Nos colégios particulares havia o ensino de outras línguas como o latim, o francês, por vezes o inglês ou o italiano. Com a criação do Ministério de Instrução Pública em 1870, disciplinas como economia doméstica, higiene, talhe, canto, ginástica e desenho apareciam pela primeira vez nos currículos obrigatórios (COSTA, 1893, p. 355). O ensino civil, moral e religioso, que compreendia o catecismo integrava, normalmente, o currículo dos colégios particulares, cabendo às famílias e à comunidade religiosa local ensinar as meninas impossibilitadas de frequentar tais estabelecimentos. Contudo, na prática, frequentavam as escolas apenas as meninas que, por facilidade de acesso ou condições financeiras, podiam fazê-lo. Nas áreas rurais, o trabalho infantil era

\footnotetext{
${ }^{2} \mathrm{O}$ Censo de 1878 é mais descritivo da situação escolar. A população absoluta era de 4.160 .315 habitantes no continente (1.995.826 - homens; 2.164 .489 - mulheres). Outro dado significativo era que a população urbana era de 490.386 (11,8\%), e as escolas, normalmente estavam distribuídas nas regiões de Lisboa, Porto, Coimbra e Braga, o que excluía o acesso à parte significativa da população. O Censo traz ainda outra informação relevante: em uma tabela sobre o analfabetismo, aponta, discriminadamente, os "que sabem ler e escrever" (437.935 homens e 175.277 mulheres), os "que sabem ler" (78.734 homens e 47.636 mulheres) e os "que não sabem ler, nem escrever" (1.479.157 homens e 1.941 .576 mulheres). Há que observar que mesmo entre os que sabiam ler, havia aqueles que liam apenas letras cursivas ou apenas as letras de forma, ou redonda como era chamada. In ESTATÍSTICA de Portugal. População: censo no $1^{\circ}$ de janeiro. 1878. Lisboa: Imprensa Nacional, 1881, p. XXI-XXII.
} 
importante complemento da renda familiar, sendo as crianças proibidas pelos pais de frequentarem as escolas, quando as havia, fato que nem a obrigatoriedade do ensino conseguiu modificar. Soma-se a todas estas dificuldades a controversa questão que no imaginário social havia o receio que a instrução pudesse masculinizar as meninas, ou afastálas dos seus deveres de mães, esposas e filhas.

Assim, para além dos preconceitos sociais e dos obstáculos inerentes e constantes na formação educacional, a mulher sofria outras limitações legais. O Código Civil Português, de 1867, também conhecido por Código Seabra, cujo autor foi António Luís de Seabra, especificava a dependência da mulher em relação ao marido. Na seção intitulada "Dos direitos e obrigações gerais dos cônjuges", alguns artigos merecem transcrição:

\section{Artigo 1184: Os cônjuges têm obrigação: \\ $1^{\circ}$ De guardar mutuamente fidelidade conjugal; \\ $2^{\circ}$ De viver juntos; \\ $3^{\circ}$ De socorrer-se e ajudar-se reciprocamente.}

Artigo 1185: Ao marido incube especialmente a obrigação de proteger e defender a pessoa e os bens da mulher, e a esta de prestar obediência ao marido.

Artigo 1187: A mulher autora não pode publicar os seus escritos sem o consentimento do marido, mas pode recorrer à autoridade judicial em caso de injusta recusa dele.

Artigo 1189: A administração de todos os bens do casal pertence ao marido, e só pertence à mulher na falta ou no impedimento dele.

(SEABRA, 1933, p. 163)

Com relação às mulheres autoras, o código estipulava ainda que, na ausência da figura do marido, o poder legal de consentimento passava para o pai, ou um irmão, sendo livre para publicar apenas as mulheres órfãs de pai, sem quaisquer tutores legais.

Nas duas comédias de que trataremos neste artigo, veremos como a educação feminina é abordada e como são questionados os papeis das mulheres na sociedade por suas protagonistas.

\section{Gervásio Lobato: breve biobibliografia}

Gervásio Jorge Gonçalves Lobato nasceu em Lisboa a 23 de abril de 1850. Seu pai, Gervásio Gonçalves Lobato, oficial maior da Secretaria da Marinha, desejava que o filho seguisse a carreira diplomática; para tanto, Lobato formou-se no Liceu, entrou no Curso Superior de Letras e tirou a cadeira de Direito Internacional na Escola Naval. Contudo, sua aptidão para as Letras manifestou-se quando ele era ainda muito jovem. Após a leitura de alguns de seus folhetins publicados no Jornal da Noite e no País, Pinheiro Chagas (1842- 
1895) convidou o jovem escritor para ajudá-lo a fundar o periódico que, após mudanças sucessivas de nome, se tornaria o Correio da manhã. Nessas páginas, sob o pseudônimo de Gilberto $^{3}$, Gervásio publicaria uma série de crônicas quinzenais, sob o título genérico de Vida em Lisboa, que posteriormente seriam reunidas no volume $A$ comédia de Lisboa.

Contribuiria ainda em muitos outros jornais e revistas como: Gazeta de Portugal, Gaz̧eta Literária, Recreio, Jornal da Noite (fundado por ele, Teixeira de Vasconcelos e outros), Progresso, Diário Ilustrado, o jornal dedicado ao teatro e à literatura $O$ Contemporâneo (fundado por ele, por Salvador Marques e Sousa Bastos), O Ocidente, entre outros. ${ }^{4}$ Nesse último, seria o responsável pela seção Crônica Ocidental, que abria as páginas da publicação com assuntos bastante heterogêneos: da crônica política para as notícias necrológicas e relatos dos acontecimentos sociais, com relevo para as notícias de cunho cultural, destacando-se, neste campo, os relatos de tudo quanto se ia passando nos palcos portugueses, sobretudo nos da capital. Após a saída de Guilherme de Azevedo, em 1880, assume a responsabilidade de autoria até a sua morte, quinze anos depois.

Paralelamente seguia com a escrita e tradução de peças e romances, sendo essa sua produção a mais estudada academicamente. Muitos volumes seguiram o mesmo curso de $A$ comédia de Lisboa, tendo sido publicados, primeiramente, como uma série de folhetins. Cronologicamente vieram a lume: A comédia de Lisboa (1878); A primeira confessada (1881) baseada na peça original Grotescos, encenada no D. Maria II em 1878; Os invisiveis de Lisboa (1886-1887) - em colaboração com Jayme Victor, romance em seis volumes; Os dramas de Africa: grande romance de sensação (1887-1888) de Francisco Leite Bastos, revisto, desenvolvido e completado por Gervásio Lobato e Jayme Victor, romance em cinco volumes; Jack, o estripador (1889) - em colaboração com Jayme Victor; Lisboa em camisa (1890); Os mistérios do Porto (1890-1891) - em colaboração com Jayme Victor, romance em cinco volumes; $A$ comédia do teatro (1893) e O grande circo (1893);

O tema recorrente de seus textos narrativos, dramáticos ou de suas crônicas é o diaa-dia da vida em Lisboa, com particular destaque para a representação da sociedade

\footnotetext{
${ }^{3}$ Gervásio adotou diversos pseudônimos ao longo da sua carreira jornalística. Para além de Gilberto houve: Fantasio, Rabecão Grande (O Pimpão), Pharés (Jornal de Domingo e Revista Universal - entre 1881-1883), Prazés, Asmodeu, Spectator (O Ocidente) e, com Jayme Victor, dividiu o nome James Middleton, quando da publicação de Jack, o estripador. SILVA, Innocencio Francisco. Diccionario Bibliographico Portuguez. Lisboa: Imprensa Nacional, 1884, p. 138. (Tomo $11^{\circ}$ )

${ }^{4}$ Outros jornais nos quais colaborou: Braz Tizana, Diário Popular, Pan, Correio da Noite, Pimpão, Fígaro, Jornal de Domingo, Século, Diário de Notícias, Crônica Moderna: revista crítica ilustrada, da qual foi diretor de janeiro de 1881 a março de 1882.
} 
acinzentada do fim de século - as classes da média e baixa burguesia e o povo, retratados com humorismo nas mais variadas situações cotidianas: a ida ao teatro, ao passeio público, à espera dos touros e aos bailes; o namoro, o casamento, o relacionamento entre pais e filhos, os problemas financeiros, as casas e sua dinâmica com os criados; as personagenstipo, como o político, o sedutor, o janota, a menina namoradeira, o atrapalhado, o ambicioso, os "invisíveis de Lisboa", como os galegos, as varinas, os comerciantes.

Toda essa imensa galeria de personagens deambulam pelas ruas alfacinhas, impregnando o texto de urbanidade e cosmopolitismo, com muitas referências ao espaço urbano da capital e seus símbolos: os teatros, os cafés (o Martinho e o Tavares), o Chiado, com seus hotéis e a Casa Havaneza, a Baixa Pombalina, com suas ruas paralelas infindáveis, o Tejo, suas panorâmicas e colinas.

Pinheiro Chagas, no prefácio que abre a publicação em volume d'A Comédia de Lisboa afirmava que "Gervásio Lobato é a observação" e que o escritor seguia "o movimento realista que se apoderou da geração contemporânea". Diria que seus textos são:

[...] cheios de verdade, de fina observação, com tipos engraçadíssimos, quadros cômicos de um chiste inexcedível. [...] Aquelas figuras são todas nossas conhecidas, temo-las encontrado cem vezes na rua, são tipos da existência contemporânea apanhados com uma verdade suprema e com um primor graciosíssimo. Tudo está desenhado por mão de mestre, com lápis que sabe em dois traços fixar para sempre no papel da carteira uma figura cômica ou uma cena burlesca (CHAGAS, 1911, p. XX).

A mesma fluidez na composição do texto, o mesmo apuro na caracterização das personagens transparece nos seus trabalhos dramáticos. O primeiro título original, Debaixo da máscara, estreado na noite de 14 de abril de 1873, no Teatro do Ginásio, conseguiu muitos elogios por parte da crítica. Luciano Cordeiro no artigo "Uma estreia" escreveria que a peça era "das mais notáveis, das mais felizes, das mais prometedoras até que temos visto nestes últimos tempos neste nosso pobre teatro nacional" (CORDEIRO, 1874, p. 119). O crítico destacaria "o corajoso realismo com que nela se denunciavam a ausência de virilidade moral, a hipocrisia do chamado grande mundo, a vida íntima de uma aristocracia de sacristia" (IDEM, p. 121). Luiz Francisco Rebello, por sua vez, escreveu as seguintes palavras:

Lobato não aprofundaria, contudo, estas qualidades nas suas obras ulteriores, entre as quais se destacam Os Grotescos (1878), Diz-se (1879), Sua Excelência (1884), O Comissário de Polícia (1890), O Festim de Baltazar (1893), limitando-se a esboçar a caricatura da média e pequena burguesia 


\begin{abstract}
lisboeta dos fins do século, retratadas nos seus ridículos, na sua vacuidade, na mesquinhez das suas ambições políticas e mundanas. Mas fê-lo com um humor certeiro (que não hesitava em recorrer ao «non-sens» no diálogo) e uma eficácia teatral que permitem dizer-se ter ele sido, para a sociedade portuguesa dos últimos anos da monarquia, o que Labiche fora para a França do II Império. As suas farsas conservam ainda hoje boa parte da sua frescura originária, enquanto tantas outras obras coevas, de mais sério empenho, irremediavelmente envelheceram.

Quase todas as comédias e farsas de Gervásio Lobato foram escritas para a companhia do Teatro do Ginásio, de que era primeira figura o ator Vale, e aí representadas com invariável agrado - o que levou um cronista da época a escrever que o teatro cômico português ali teve então «o seu trono, a sua corte e o seu rei» (REBELLO, 1978, p. 66)
\end{abstract}

Como dramaturgo, Gervásio aventurou-se nos mais variados gêneros: dramas, dramas fantásticos, comédias, farsas, revistas, monólogos, mágicas, vaudevilles, óperas cômicas, zarzuelas e operetas. Seria nesses gêneros musicados que se formaria a parceria de longos anos de Lobato com o também consagrado autor teatral, D. João da Câmara (18521908). Juntos teriam enorme êxito com as operetas nacionais O burro do senhor Alcaide (1891), O valete de copas (1892), O solar dos Barrigas (1892), Cocó Reineta \& Facada (1893), O testamento da velha (1894), musicadas, em sua grande maioria pelo maestro Cyríaco de Cardoso.

Das suas peças originais, para além de A Burguesa, destacamos: A condessa Heloísa, comédia em um ato (1878); Medicina de Balzac, comédia em três atos (1879); Diz-se, comédia em quatro atos (1879); Sua Excelência, comédia em três atos (1884), O Seguro de Vida, comédia em dois atos (1885); As médicas, comédia em quatro atos (1888), escrita em parceria com Fernando Caldeira (1841-1894); O comissário de polícia, comédia em quatro atos (1890); Em boa hora o diga, comédia em três atos (1891); As noivas de Enéas, comédia em quatro atos (1892) e O festim de Balthazar, farsa em um ato (1892).

Não há nenhuma obra que reúna a sua produção original, não há nenhuma biografia publicada a seu respeito, não há trabalhos de fôlego a respeito da sua obra. Apenas pequenos capítulos em coletâneas de literatura portuguesa, alguns artigos que versam, invariavelmente, a respeito da sua obra romanesca e citações esparsas em trabalhos de diferentes temáticas. Sua produção jornalística, como crítico teatral, também jaz esquecida nas páginas dos inúmeros periódicos nos quais colaborou assiduamente. Lobato viria a falecer em sua residência, em 26 de maio de 1895, aos quarenta e cinco anos, 
deixando a esposa, D. Maria das Dores Pereira d'Eça d'Albuquerque Lobato, e três filhas: Sara, Maria das Dores e Piedade.

Após este breve incurso biobibliográfico é possível constatar a relevância do autor para a dramaturgia portuguesa. Em 1884, o jornal O Imparcial de Coimbra, buscava determinar os vinte e cinco escritores portugueses mais notáveis na atualidade, realizando um inquérito não apenas com as autoridades acadêmicas, mas, também, com os leitores. Gervásio Lobato, na $19^{a}$ posição, figurou entre os nomes de Camilo Castelo Branco, Eça de Queiroz, Teófilo Braga, Antero de Quental, João de Deus, Ramalho Ortigão, Oliveira Martins, entre outros. A opinião de Duarte Ivo Cruz é categórica, alçando Lobato como um marco do seu tempo e de tempos posteriores, por causa de um "programa de comédias de crítica realista de costumes, muitíssimo bem armadas e ainda hoje muito engraçadas, que fizeram escola no teatro e no cinema" (CRUZ, 2001, p. 191) ${ }^{5}$.

As personagens dramáticas femininas de Gervásio Lobato sempre tiveram vulto em sua produção, importância que se observa em vários títulos de suas peças ${ }^{6}$. De cariz variado, passando por todas as classes sociais, as personagens possuem maior ou menor grau de caracterização, atendendo sempre ao jogo de cena de cada enredo. Se fossemos elencar algumas das características principais das peças gervasianas seriam: falas fluídas, rápidas, respostas sagazes e repletas de humorismo, com bastante interatividade entre as personagens e movimentação de cena.

\section{A burguesa e a pré-feminista D. Leonor}

A comédia em um ato estreou no Teatro da Trindade, em 2 de janeiro de 1882, na noite de benefício ${ }^{7}$ do ator e ensaiador Augusto de Mello. Uma Viagem à Itália, tradução de Gervásio Lobato para a peça Un voyage d'Agrément, de 1881, escrita por Edmond Gondinet (1828-1888), completou o repertório da noite.

\footnotetext{
5 A peça $O$ comissário de polícia teve duas adaptações para o cinema: a primeira estreada em 2 de fevereiro de 1920, produzida pela Invicta Film; a segunda datada de 1953, realizada pelo diretor português Constantino Esteves. O festim de Balthazar, por sua vez, teve sua adaptação para o cinema dirigida por Artur Ramos em 1958. Outras peças teriam adaptação para TV feitas pela RTP entre as décadas de 60 e 70.

${ }^{6}$ A condessa Heloísa, A burguesa, A gigante Golias, As manas Felgueiras, As noivas de Enéas dão preponderância aos papeis femininos.

7 Segundo o Diccionario do theatro portugués de António de Sousa Bastos, "chama-se espetáculos em benefício aqueles cujo produto, deduzidas as despesas ordinárias do teatro, pertencem ao artista beneficiado" (BASTOS, 1908, p. 24). Os benefícios eram importante complemento de renda para os artistas e vinham estipulados em seus contratos de trabalho. Normalmente, cada artista tinha direto a dois benefícios por temporada teatral.
} 
A distribuição dos papeis foi entregue aos respectivos atores: D. Leonor Gonçalves (Anna Pereira), D. Mafalda Payalvo (Amélia Barros), Visconde de Ruivães (Augusto de Mello), Thadeu Gonçalves (Leoni), Bernardino Payalvo (Silva Pereira). A ação da peça se passa em Lisboa, no ano de 1881.

O enredo pode ser rapidamente resumido: D. Leonor e seu pai vão da província para Lisboa, pois Thadeu precisa assumir a sua cadeira na Câmara, para a qual foi eleito. Ambos ficam hospedados na casa da irmã de Thadeu, D. Mafalda, viúva, e de seu jovem filho Bernardo, que em poucos dias de convivência, apaixona-se pela prima. O pai de D. Leonor tem planos em casá-la com o Visconde de Ruivães, garantindo-lhe, assim, a entrada no meio aristocrático. Entretanto, D. Leonor não aceita nenhum dos dois pretendentes e, por fim, seu pai não consegue ocupar a cadeira para a qual foi eleito, uma vez que no dia da posse, sai um decreto dissolvendo as Câmaras.

O ato tem por cenário: "Uma sala rica e elegante. Mesas, sofás, chauffeuses, confortables e um piano com músicas de Chopin sobre a estante. Livros sobre as mesas, retratos antigos de família nas paredes, etc" (LOBATO, 1912, p.3). A descrição do cenário é significativa, uma vez que esclarece ao espectador a posição social da família, mostrando, por meio dos retratos, a sua ancestralidade, situação que será constante lembrada pela viúva D. Mafalda a todos os membros familiares, como se observa no início da peça. No decorrer das cenas adivinha-se que as partituras e livros pertencem a Leonor.

A comédia tem início com uma leve discussão entre D. Mafalda e a sobrinha:

MAFALDA. - (velha empertigada, de cabelos tintos, muito arrebicada, mas com ares grandes e ridiculos de retrato de família) Não consinto, minha sobrinha, não posso consentir...

LEONOR. - Mas, minha tia...

MAFALDA. - Não posso consentir que uma descendente, em linha reta, dos célebres Payalvos, empregue as aristocráticas mãos a fazer pudins, como qualquer cozinheira de brasileiro rico...

LEONOR. - Mas, minha tia...

MAFALDA. - Menina... lembre-se que os Payalvos estiveram em Alcácer-Quibir.

LEONOR. - E eu estarei no fogão; eles, perderam lá um reino, eu ganharei cá um pudim... talvez não seja tão nobre, mas é muito mais saboroso, verá...

[...] MAFALDA. - Bonito! Vens fresca da província! ... Teu pai pode limpar a mão à parede, tirou-te de Lisboa, de ao pé de mim, debaixo dos meus conselhos, meteu-te numa aldeia durante cinco anos, e para quê? Para fazer de ti uma criada de servir!

LEONOR. - Ainda bem! Ao menos confessa que tenho algum préstimo, que sirvo para alguma coisa. 


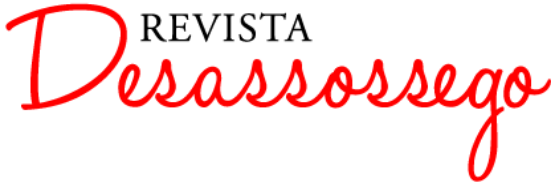

DESASSOSSEGO 17 | JUN/2017 | ISSN 2175-3180

DOI: http://dx.doi.org/10.11606/issn.2175-3180.v9i17p102-127

MAFALDA. - Leonor... uma verdadeira fidalga, não serve para coisa alguma.

LEONOR. - É essa a sua ocupação, minha tia? ... Não se deve cansar muito (LOBATO, 1912, p. 3-4).

De um lado a tia, perfeita representação da matrona antiga, com comportamento e pensamento ultrapassados, que vive só pelas aparências, pela representação do passado, presa a códigos de conduta muito rígidos. De outro, Leonor, a moça de boa linhagem, criada pelo pai viúvo na província, longe da única figura feminina que poderia 'the dar exemplos de comportamento', longe das representações sociais inerentes da capital, questionadora dos hábitos e costumes urbanos que lhe parecem falsos e vazios.

A discussão entre ambas continua:

MAFALDA. - Basta! Basta! Foi isso que aprendeste durante estes cinco anos?

LEONOR. - O que queria a tia que uma pobre rapariga fizesse na província?

MAFALDA. - O que queria? Queria que lesse o livro dos seus brasões, a história dos seus avós.

LEONOR. - A história dos meus avós?! A tia já leu?

MAFALDA. - (à custo) Não.

LEONOR. - E queria então que eu a lesse? Que procurasse esse trágico suicídio?

MAFALDA. - Leonor, uma fidalga do nosso sangue só pode ter duas desculpas de não ler a história dos seus maiores; ter cataratas, (baixo) ou não saber ler.

LEONOR. - Ai! Meu Deus! Minha tia! ... Então mande já, já chamar o Mascaró.

MAFALDA. - (grave) Não preciso, graças a Deus, vejo perfeitamente.

LEONOR. - (maliciosa) Então...

MAFALDA. - (irritada) Não admito zombarias, Leonor... (LOBATO, 1912, p. 4)

Aqui temos evidenciada a questão, anteriormente abordada, do analfabetismo feminino. D. Mafalda, com toda a sua arrogância senhorial, que julga ser papel de uma fidalga não fazer nada que rebaixe a sua posição, envergonha-se da sua condição, quando esta foi criada, sobretudo e de forma contraditória, por estes mesmos antepassados que ela tanto venera e reverencia. Ter permanecido analfabeta, enquanto seu irmão era eleito para a Câmara, mostra a diferença discrepante de educação recebida por ambos.

$\mathrm{Na}$ cena seguinte aparece Thadeu, que adentra a sala com um papel nas mãos, ensaiando disfarçadamente o seu discurso de posse, uma vez que gostaria que todos acreditassem que ele iria proferir a sua fala naturalmente, sem maiores cuidados. Quando 
Mafalda menciona que não irá assistir ao discurso, pois não quer frequentar a Câmara baixa, Thadeu responde:

THADEU. - Mana, na constituição não há altos nem baixos, é tudo caminho direito, somos todos iguais, fraternidade, igualdade, liberdade é o dilema... (vê o papel) não, não, o lema da nossa bandeira, sr. Presidente.

LEONOR. - (rindo) Sr. Presidente! Ah! Papá, bem dizia eu, o papá anda a aboborar um discurso... Vou hoje à câmara ouvi-lo.

THADEU. - Não, não, que me podes perturbar.

MAFALDA. - E é com esses discursos tais que sua filha faz pudins!

THADEU. - (espantado) Hein?

MAFALDA. - É com essas ideias de liberdade e com outras tolices assim.

THADEU. - (exaltando-se) Tolices! ... Peço a pala... (cala-se)

MAFALDA. - Tolices, repito, é por causa dessas tolices que sua filha faz pudins, como qualquer cozinheira de casa de hóspedes (LOBATO, 1912, p. 5).

Para D. Mafalda a liberdade deve ser restritiva segundo o papel que cada indivíduo deva exercer na sociedade. A sobrinha, mesmo que use o seu tempo com afazeres domésticos, torna-se indigna ao aproximar-se, por suas atitudes, das classes tidas como inferiores.

Enquanto Leonor se dirige para a cozinha, a pedido do pai, para fazer um pudim para o Visconde de Ruivães, colega de câmara de Thadeu, este conversa com sua irmã sobre as suas intenções:

THADEU. [...] E a filha desse Gonçalves que a senhora trata de resto, talvez que daqui a bem pouco tempo, tenha a engrinaldar-lhe a fronte, uma coroa de Viscondessa.

MAFALDA. - (serenando) O quê? O mano pensa em casar Leonor com algum Visconde?

THADEU. - Agora como falo em Viscondes já sou mano.

MAFALDA. - Sr. Gonçalves, tenho no meu sangue nobreza demais. [...]

Querem ver que é com o Visconde de Ruivães?

THADEU. - Talvez... talvez...

MAFALDA. - Mas parece-me que ela não está muito inclinada para o Visconde.

THADEU. - Há de se inclinar... eles já se falaram algumas vezes... ele já lhe tem feito o seu pé...

MAFALDA. - De alferes, hein?

THADEU. - Não senhora, de deputado... já me deu a entender que gostava dela...

MAFALDA. - E ela?

THADEU. - Ela não me deu nada a entender... e quando eu lhe falei nisso riu-se...

MAFALDA. - Mau sinal. 
THADEU. - Qual mau sinal? Queria que ela chorasse? Ele tem muito talento, é muito bem falante... vem cá hoje... ela não é tola, hão de se entender bem...

MAFALDA. - Mas o visconde é nobre?

THADEU. - Eu sei lá se ele é nobre! É visconde, que mais Nobreza quer?... E tem de seu... ela tem os seus quarentas contos de dote... E, antes de fecharmos as cortes...

MAFALDA. - Temos a Leonor casada, hein?... (LOBATO, 1912, p. 5-6)

$\mathrm{O}$ arranjo de casamento entre uma moça jovem e um homem bem mais velho foi tratado anteriormente por Gervásio em outras comédias, aliás, esse tema aparece já aparece no teatro vicentino, em $O$ velho da Horta. Esta matéria aparece em A Condessa Heloisa e, posteriormente, será recuperada e desenvolvida em Sua Excelência.

Os casamentos arranjados eram muito comuns e feitos para preservar títulos, quando os havia, ou como forma de ascensão social e estabilidade econômica. Uma jovem rica burguesa que se casava com um homem mais velho, porém membro da aristocracia, mesmo que sem grandes posses, era considerado um excelente arranjo. É exatamente este o intuito do pai de D. Leonor Gonçalves na comédia $A$ burguesa.

Entretanto, o Visconde de Ruivães não consegue impressionar Leonor, ao contrário, suas falas pretensiosas e preconceituosas a insultam profundamente, como veremos na cena X. Ambos tinham se encontrado no Teatro S. Carlos, na representação de Huguenotes, de Meyerbeer e travado uma pequena discussão sobre as mulheres portuguesas, tema que o Visconde de Ruivães traz novamente à tona:

VISCONDE. - [...] É uma felicidade, a gente poder hoje entender-se com uma senhora portuguesa.

LEONOR. - Ah! Vejo que V. Ex. ${ }^{a}$ quer continuar o assunto interrompido pelo coro dos Punhais... Pois realmente pensa muito mal das suas compatriotas, julgava que pensava isso somente quando ouvia $\mathrm{o}$ dueto de Valentina e Raul.

VISCONDE. - Não, penso sempre, ou para melhor dizer, não penso nem mal, nem bem, não penso nada, que é tudo o que se pode pensar delas.

LEONOR. - Muito obrigada, sr. visconde; sou portuguesa. (LOBATO, 1912, p. 12)

Pouco depois, o visconde pergunta se D. Leonor não odeia suas patrícias:

LEONOR. - Odiá-las! Por quê?

VISCONDE. - Porque não há nada mais impertinente, mais aborrecido, mais sensaborão, do que as portuguesas. Vejamos o que é a portuguesa.

LEONOR. - Sou eu.

BERNARDINO. - É a mamã.

MAFALDA. - Cale-se menino. 
VISCONDE. - Peguemos na portuguesa, espetemo-la no alfinete da nossa análise e observemo-la ao microscópio da nossa razão; e façamos a análise com tanta mais frieza científica; quanto fica desde já assente que V. Ex. ${ }^{a}$ não o é... A portuguesa é uma criatura pequena - há as desde 50 centímetros até metro e meio - ordinariamente é trigueira, dum tom escuro de carne cozida, se lhe dá para ser branca tem os ares deslavados duma parede caiada. Isto, por fora; por dentro é a mesma coisa, o espírito é tão esbranquiçado, como uma parede de chaminé burguesa, a inteligência é profundamente trigueira, isto é, tem pouca luz.

LEONOR. - Remédio: Fósforo, uso interno.

VISCONDE. - E precisa realmente de fósforo, não para a inteligência, mas para os ossos que são fracos, corroídos pela anemia, rendilhados, como os agulheiros e dedais que a China nos manda.

LEONOR. - Magnífico, é um novo aspecto da população feminina de Portugal - uma coleção de caixas de costura!

VISCONDE. - Mas muito menos procuradas que as chinesas: porque como objetos de luxo, falta-lhes a arte, como objetos de uso falta-lhes o préstimo. Sim, porque realmente o que faz a mulher portuguesa em qualquer das esferas sociais? Na família dá pontos em meias, (Mafalda tosse) cose a roupa da lavadeira (idem) e faz doces para a sobremesa. (idem) BERNARDINO. - Mamã quer pastilhas?

LEONOR. - (nervosa) Magnífico, esplêndido!

VISCONDE. - Na arte, toca no piano as romanzas da Traviata e os fados de Cascais, borda chinelas para os namorados, ou comemora em escumilha os amores de Inês que já passaram. Em literatura lê Feuillet, e embriaga-se com a orchata açucarada da fábrica Júlio Diniz; na religião confessa-se a miúdo, defende a infalibilidade do papá, a indissolubilidade do casamento, e salva a alma pelo estômago, não comendo carne à sextafeira. $\mathrm{Na}$ política, os altos problemas que a agitam é arranjar o lugar de amanuense do tesouro para o mano, o de $3^{\circ}$ oficial da Alfândega para o tio, e o de guarda a cavalo para o derriço da cozinheira. (LOBATO, 1912, p. 12-13)

Sem saber, o visconde de Ruivães lista todas as atividades diárias de Leonor. Pouco antes da entrada do visconde, Bernardino havia chegado com várias compras para a prima: partituras de música, livros, entre eles A Família Inglesa de Júlio Dinis, itens culinários... Ruivães, neste sentido, tem o discurso muito próximo aos propagados pela Geração de 70 sobre a condição e a educação feminina em Portugal. Basta recuperarmos uma crônica de Eça de Queiroz (1845-1900) extraída das Farpas, que integra o volume Uma campanha alegre, datada de março de 1872: "As meninas da Geração Nova em Lisboa e a Educação Contemporânea".

Antes de dar início ao texto, Eça de Queiroz pede desculpas por sua pena nem sempre ser glorificadora das mulheres, justificando que "a tinta moderna é diluída em verdade" (QUEIROZ, 2004, p. 413). Quanto à aparência das jovens, escreve:

As meninas solteiras. Vejamos o tipo geral de Lisboa: é uma pessoa magrita, amarelada, com um andar débil, ligeiramente ondulado, um 
grande puff no vestido, penteado difícil e espesso, pequenino chapéu, o olhar sem ingenuidade, sem hesitação e sem temor. O primeiro sinal saliente é a debilidade e a anemia (QUEIROZ, 2004, p. 414).

\section{Quanto aos afazeres cotidianos:}

O dia de uma menina de dezoito anos é assim dissipado: almoça, vai-se pentear, corre o Diário de Notícias, cantarola um fadinho pela casa, ajeita-se numa cadeira, pega no crochet ou na costura, deixa-a, vai à janela, passa pelo espelho, dá duas pancadinhas no cabelo para o compor, dá mais dois pontos no trabalho, deixa-o cair no regaço, come um bocadinho de doce, conversa vagamente, dedilha uma ária da moda no piano, levanta-se, volta ao espelho e assim vai puxando o tempo pelas orelhas, fatigada de ociosidade e bocejando as horas. (QUEIROZ, 2004, p. 417)

Quanto ao seu domínio e leituras:

Em Portugal, uma mulher, excluída da política, da indústria, do comércio, da literatura, pelos hábitos ou pelas leis - fica apenas de posse de um pequeno mundo moral, seu elemento natural - a família. Infinito domínio, o mais profundo, o mais belo, o mais grave. As mulheres queixam-se. Disto sai que as senhoras reunidas giram - como borboletas em torno de um globo de candeeiro - em volta deste centro de exame: vestidos, dispensa e casamento. [...] Depois acham tudo vulgar, insípido, tranquilo. Querem ser impressionadas, sacudidas, abaladas - preferem o drama e o romance. [...] Aqui leem Ponson $d u$ Terrail, ou mais irritantemente, os falsos realistas, Dumas Filho e a sua banda de analistas lascivos. (QUEIROZ, 2004, p. 422 et. seq.)

Há muitas proximidades entre os discursos da personagem visconde de Ruivães e do autor d'O Primo Basílio. Contudo, a escrita queiroziana mostra-se mais consciente das relações entre causa e efeito e compreende que o comportamento das jovens é fruto da parca educação que recebem. A família, para Eça de Queiroz, encontrava-se em grave processo de dissolução, uma vez que se alicerçava sobre valores e bases morais falsas.

Leonor, nossa personagem, sente-se profundamente ofendida pela fala do visconde, não por este lhe mostrar seus hábitos como que em um espelho, mas, justamente, por este não reconhecer a contínua exclusão e confinamento das mulheres na sociedade. E se das 'mulheres portuguesas' nada se tem para pensar, recuperando a fala do visconde, é por seu longo histórico de anulação e obscurecimento.

Porém, Leonor não irá aceitar docilmente a preleção do visconde e, poucas cenas depois, afirma de forma categórica não odiar as suas patrícias, mas sim, os seus patrícios:

LEONOR. - Eu odeio os portugueses, exatamente por causa disso; esses portugueses, rançosos, incômodos, impertinentes que têm umas 
ideias cheias de bolor a respeito da família, do amor e da mulher. Esses sujeitos cômicos que imaginam que a mulher foi feita mais para esposa do que para cidadã, e a esposa mais para seu marido do que para toda a gente.

MAFALDA. - Menina!

LEONOR. - Uns caturras originalíssimos, que quando casam exigem da mulher a fidelidade de toda a vida, como se houvesse contratos permanentes, e se a fidelidade, o privilégio exclusivo de ser amado, não fosse um atentado antigo contra a liberdade moderna; uns patetas que querem que a mulher trate do governo da sua casa, em vez de tratar da salvação do país, que faça meia em vez de fazer propostas de lei, que trate dos filhos em vez de tratar das eleições, uns imbecis que preferem que ao entrarem à noite, em casa, a esposa lhe peça um beijo, em vez de pedir a palavra, e lhe responda às suas carícias em vez de responder... ao discurso da coroa! VISCONDE. - Perdão... mas pode-se conciliar.

LEONOR. - Nada de conciliações: sou intransigente: extrema esquerda! Liberdade ampla, liberdade completa! A mulher é igual ao homem. Quero os mesmos direitos, os mesmos deveres, quero em vez de coser, legislar, em vez de tomar a roupa à lavadeira, tomar contas ao ministério, em vez de remendar os vestidos dos filhos, deitar passagens na túnica esburacada da Carta Constitucional. E não compreendem isto os meus patrícios, e é por isso que os odeio, a todos, a todos exceto a V. Ex. ${ }^{a}$ que pensa isto mesmo, e a meu primo que não pensa coisa nenhuma (LOBATO, 1912, p. 20-21).

Nesta alocução inflamada Leonor demonstra não ser a provinciana que julgavam, ignorante e submissa. Ao contrário, defende veementemente a emancipação feminina, a igualdade entre os gêneros, o direito ao voto, ao trabalho, a participação ativa na vida política e econômica do seu país. De maneira constante, ao longo de toda a peça, Leonor questionou os papeis que, sucessivamente, lhe eram impostos: o de fidalga, o de filha obediente que acata as vontades do pai (neste caso o casamento com Ruivães), o de mulher portuguesa comum e subserviente, o de jovem romântica que se derreteria pela confissão apaixonada do primo, quando este lhe pede em casamento. Assim, liberta de todas as amarras e convenções pré-estipuladas, Leonor se expressa sem reservas ou medo de sofrer represálias.

A peça termina com o visconde e o primo querendo saber qual a decisão dela quanto aos pedidos de casamento feitos por ambos, a que Leonor responde:

BERNARDINO. - Prima, queira ter a bondade de escolher... eu ou o sr. visconde.

LEONOR. - (olbando para ambos) Nem um... nem outro...

VISCONDE. - Ora essa, minha senhora, por quê??

LEONOR. - V. Ex. ${ }^{a}$ por causa de querer o divórcio...

BERNARDINO. - E eu prima? 


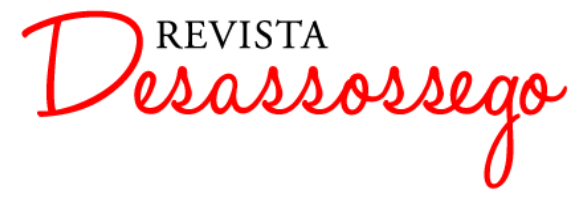

DESASSOSSEGO 17 | JUN/2017 | ISSN 2175-3180

DOI: http://dx.doi.org/10.11606/issn.2175-3180.v9i17p102-127

LEONOR. - O primo? ... Por causa de não o haver! (LOBATO, 1912, p. 24).

As críticas teatrais foram bastante reservadas quanto à estreia da peça. No dia imediato, o jornal $A$ Revolução de Setembro publicou uma nota exígua dizendo que " A burguesa agradou muito". O Diário Ilustrado foi o único jornal que exibiu uma nota mais alongada sobre a comédia, escrita nada menos que pela pena de Gabriel Claudio, pseudônimo de Guiomar Torresão, colaborada assídua do periódico e responsável por várias críticas teatrais e pela sessão "Pizzicatos". Escreveu ela sobre a peça:

Há nessa graciosa bluette algumas cenas deliciosamente trabalhadas, um tipo que constitui um achado, o da fidalga, orgulhosa da árvore genealógica dos Payalvos, que entende que uma senhora não deve saber fazer nada, e alguns diálogos excepcionais entre D. Leonor e o visconde, ricos de observação e de ditos felizes, que se cruzam, faiscando, pelas verdades que contêm. [...] Outra observação; a burguesa, primorosamente interpretada pela atriz Anna Pereira, provocou espanto geral dos espectadores da Trindade. As mulheres aplaudiram furiosamente, os homens responderam com pateada, ou com um silêncio enregelante. Conclusão o frio morde desesperadamente. Ainda a esta hora a pena treme, periclitante, nas minhas mãos congeladas!... (TORRESÃO, 1894, p. 2).

O silêncio da crítica pode ser justificado pelo tema polêmico que a comédia aborda e, como bem explicitado por Torresão, pela diferente recepção entre homens e mulheres. O público feminino viu os seus direitos reivindicados no palco, seus desejos expressos pelas falas da personagem, enquanto o público masculino viu apenas os seus direitos ameaçados. Fialho de Almeida (1857-1911), em um artigo sobre Guiomar Torresão, escreve: "A mulher entre nós está ainda muito na condição de serva do marido, e convém à constituição da família que ela seja de nível mental inferior, para aceitar sem relutância os misteres obscuramente sagrados da casa, desde a caçarola ao leito conjugal" (ALMEIDA, 1899, p. 3).

De nosso conhecimento, a peça teve, pelo menos, duas montagens posteriores: em 1932, no Teatro D. Maria Pia, em Leiria, encenada pelos antigos alunos do Liceu de Leiria e, mais recentemente, em maio de 2007, no Centro Cultural Vila Flor em Guimarães, pelo Grupo de Teatro de Campelos. Na chamada do espetáculo, no site do Centro Cultural, constavam os seguintes dizeres:

"A Burguesa" é um retrato fiel da sociedade da época, caracterizado pela importância do dinheiro e do estatuto como forma de promoção social. Retrata conflitos ainda hoje actuais, apesar de todas as conquistas sociais 


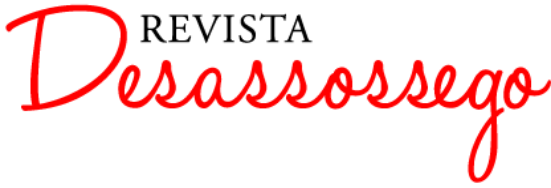

DESASSOSSEGO 17 | JUN/2017 | ISSN 2175-3180

DOI: http://dx.doi.org/10.11606/issn.2175-3180.v9i17p102-127

e dos avanços tecnológicos que entretanto se verificaram. A igualdade de géneros e a forma mais ou menos ardilosa para se conseguir um estatuto social e político, são alguns dos temas tratados na peça interpretada pelo Grupo de Teatro de Campelos. Devido ao seu carácter actual são temas ainda hoje objecto de discussão e mediatização (http:/ www.ccvf.pt/conteudo.php?id=19\&cat=4\&prog=all\&on=false \&evento=506; acesso em 19 de janeiro de 2016)

Provavelmente esta foi a primeira peça original portuguesa onde o tema da igualdade de gêneros foi abordado em um palco nacional. Talvez a segunda, seja justamente a que será abordada na sequência, Educação Moderna de Guiomar Torresão.

\section{O ofício de escritora}

Em Portugal, tanto os homens que escrevem são profusos, quanto raras as mulheres que vivem de escrever. No número destas, ainda mais raras as escritoras dignas de conceito, e quase metade são apenas parolosas pedagogas, ou inofensivas delambidas (ALMEIDA, 1899, p. 3).

Guiomar Delfina de Noronha Torresão, escritora, jornalista, contista, dramaturga, romancista e poetisa, nasceu em Lisboa em 26 de novembro de 1844. Órfã de pai aos oito anos de idade, cedo precisou começar a trabalhar para ajudar no orçamento doméstico da família. O trabalho de costura da mãe pouco dava para cuidar das três filhas, assim, como havia recebido boa instrução, passou a ensinar o francês e os conhecimentos primários para algumas alunas.

Encontrou na escrita não apenas um meio para se expressar, mas, também, uma forma de aumentar os ganhos. Seu primeiro livro, Uma alma de mulher, foi escrito quando possuía apenas dezesseis anos, mas impresso muitos anos mais tarde, em 1869.

Para escrever e ser publicada sem maiores restrições ou polêmicas, precisou recorrer ao uso de pseudônimos, assim assinava Gabriel Claudio, Delfim de Noronha ou Delfina de Noronha, Roseball, Scentelha,Tom Ponce ou Sith. Cedo mostrou inclinação para o teatro, tendo subido à cena a imitação em um ato $O$ século XVIII e o século XIX, no Teatro D. Maria II, em 1867, quando contava com 23 anos de idade. Traduziu várias peças das quais destacamos: Mademoiselle diabrete, Dois garotos, Menina do telefone, Musotte, Mártir, Condessa Sarah, Dionísia, Clara Soleil, Noiva dos Girassóis, entre outras. Originais seus apenas dois: a comédia em um ato O fraco da baronesa (1878) e Educação Moderna (1891).

Sua produção mais prolífera foi, sem dúvida, nos periódicos. Escrevia quase que diariamente para o Diário Ilustrado e o Repórter, foi redatora da revista semanal Ribaltas e 
Gambiarras (1881), onde publicava artigos literários e teatrais, fundou e dirigiu o Almanaque das Senhoras que circulou entre os anos de 1871 e 1928, até o ano da sua morte em 1898. Suas crônicas e contos eram, por vezes, compilados em volume. É o caso de Meteoros (1875) e No teatro e na sala (1881). Como romancista e contista publicou alguns títulos como o volume de contos Rosas pálidas (1873), o romance histórico A família Albergaria (1874), entre outros trabalhos.

Faleceria no dia 22 de outubro, vítima de problemas cardíacos.

Guiomar Torresão foi, provavelmente, a primeira mulher a viver inteiramente do seu ofício de escritora, fato que lhe rendeu muitos momentos difíceis e um sem número de dissabores. Vários são os escritores que, após a sua morte, falaram da sua vida de trabalho. D. João da Câmara, n'O Ocidente, escreveu:

Eram realmente notáveis as qualidades porque esta senhora se impusera à admiração de todos durante longos anos de trabalho assíduo. Dotada duma inteligência e duma atividade muito acima do vulgar, havendo-se dedicado às letras desde muito nova, são muitos os volumes que deixou [...]. Dotada de uma força de vontade que seria rara num homem e era de admirar numa senhora, trabalhava constantemente, tendo pelo teatro uma notável predileção. [...] conhecera perfeitamente as duras batalhas da vida, em que muita vez conseguiu vencer, em que nunca se lhe viu um esmorecimento. Trabalhava constantemente e defendia com denodo o seu trabalho. Assim lutou anos e anos (CÂMARA, 1898, p. 241).

Entretanto, de todos os depoimentos que lhe prestaram homenagens, o mais significativo e simbólico é o de Fialho de Almeida, que figura no Almanaque das Senhoras para 1900:

Guiomar Torresão, que acaba de morrer cardíaca do pavoroso esforço de reagir contra a mesquinharia do espírito (ou antes da falta de espírito) do tempo, era uma criatura fadada para menos obscuros destinos do que esse que a amesendou em Lisboa, a arreglar almanaques, e a escrever crônicas elegantes. Grandemente talhada, forte, e dum caráter autônomo de onde saem as iniciativas fecundas que individualizam na vida as naturezas de comando, esta mulher só teve, para ser verdadeiramente alguém, um obstáculo - o meio onde apareceu e se fez gente.

Em Londres, ou Paris, teria sido ilustre; em Lisboa quase que a quiseram tornar cômica.

[...] Guiomar Torresão não tinha pai nem irmãos que exigissem contas aos desrespeitadores eméritos das mulheres sós; e não tendo constituído família, nem tendo fortuna própria, achou-se na condição de ter que ganhar ela mesma o seu prato e os seus vestidos, escrevendo para jornais todos os dias - isto é, cozendo à pena, em vez de cozer à máquina, e não tirando deste esgotante martírio sequer talvez o que as pobres costureiras auferem nos armazéns onde trabalham. [...] 


\begin{abstract}
Houve até um momento em que Guiomar Torresão foi a cabeça de turco do jornalismo irresponsável - em notícias de bastidores, artigos de sátira, sueltos de rua, gazetinhas, o nome da pobre e ilustre mulher, corria, entre motejos obscenos e miseráveis duetos, babujado pela covardia dos sarrafaçais, e exposto grotescamente às vaias imbecis da multidão. O motivo desta guerra ignóbil de muitos homens, contra uma mulher desprevenida? - Inconfessável. E por ignomínia de um povo ainda grosseiro, e desmoralizado pela falta de exemplos dignos, temos de dizer que são casos estes vulgares na troca-tintice da vida artística e literária (ALMEIDA, 1899, p. 4 et. seq.)
\end{abstract}

Apesar de Fialho de Almeida considerar inconfessável a razão para tantas manifestações de desrespeito, é evidente que o motivo de tantos ataques e críticas era o fato de se tratar de uma mulher. Uma mulher escritora. Vejamos como o tema da educação feminina aparece na sua já nomeada peça.

\title{
Educação moderna: diálogos entre Christiana e Gabriela
}

A comédia estreou no Teatro do Ginásio, na noite de 28 de março de 1891, um sábado de aleluia, e foi especialmente escrita para o benefício do ator Júlio Soller. No repertório havia ainda a comédia em um ato Lágrimas de mulher (1866) e a declamação do poema Ermesto. Nas breves páginas intituladas 'Conversando', espécie de prefácio do volume impresso, Guiomar Torresão discorre sobre o processo de concepção do texto. Diz que escreveu a comédia em apenas três semanas para obsequiar o festejado ator com um original seu, prova de apreço e consideração (TORRESÃO, 1894, p. V-VI).

Educação moderna foi ensaiada por Leopoldo de Carvalho e representada por: Beatriz Rente (Christiana); Jesuína Marques (Antonia Antunes), Judith (Leontine), Bárbara Volckart (Gabriela), Amélia Garraio (Romana), Silvéria (Petronilha), Juliana (Zinha Mascarenhas), Júlia Moniz (Maria, criada), Adelina Nunes (Rita, criada), Júlio Soller (Alberto Martins), Marcelino Franco (Felisberto Antunes), Cardozo (Guilherme Antunes), Eloy (Júlio de Lemos), Ferreira (Pedro de Mendonça), Telmo (Cesário) e Senna (Romão, criado).

Christiana, filha de Antonia e Guilherme, regressa de Paris após três meses de estudos. Volta completamente mudada, não apenas nos modos de vestir ou de portar-se, mas com outras ideias e pensamentos. Na França descobre que as mulheres que sofrem de nervos - ou que não são compreendidas por suas atitudes - são acusadas de sofrer de histerismo, o que faz com que grande parte da população feminina em Paris seja definida como histérica. Seus pais querem casá-la com Júlio, seu amor de juventude e com quem 
trocou confidências e cartas. Entretanto o fato do casamento ser tratado sem o seu consentimento, provoca-lhe grande desgosto, negando-se a aceitar o estabelecido. Aproxima-se assim de Alberto, homem que conheceu na viagem de retorno, cujas ideias pareciam estar ajustadas com o seu novo modo de pensar. Posteriormente descobre-se que Alberto já era casado com Gabriela, fato suspeitado por seu pai e tio, que criam um ardil para mostrar-lhe a realidade. Gabriela, por sua vez, abandona sua condição de gata borralheira e emancipa-se. No fim, Christiana e Júlio ficam juntos.

Pouco antes da chegada da protagonista em casa, Cesário, guarda-livros de Guilherme, pede autorização à D. Antonia para ler uns versos que compôs para a ocasião. Ela responde:

ANTONIA. - Com muito gosto; mas é melhor guardar isso para minha filha. Ela aprecia muito mais a poesia do que eu. Não admira, teve outra educação. Aprendeu em um dos melhores colégios a recitar, falar as línguas, tocar, cantar, dançar, etc. No meu tempo, não se tratava de nenhuma dessas prendas. Só ensinavam a gente o que era indispensável para ser uma boa dona de casa: cozer, marcar, ler, escrever, catecismo, tabuada, quer dizer contas de somar, multiplicar e diminuir.

CONSELHEIRO. - (rindo) Para desempenhar o ofício de dona de casa, basta saber a conta de diminuir (TORRESÃO, 1894, p. 6).

A educação de ambas não podia ser mais diferente, nem servir tão opostos propósitos. Maria Amália Vaz de Carvalho (1847-1921), outra profícua escritora portuguesa oitocentista, em seu livro Cartas a uma noiva, publicado no mesmo ano da peça, criticava veemente a educação moderna recebida por Christiana, procurando valorizar a instrução recebida por D. Antonia:

Em que podem ser úteis ao futuro marido [...] os desenhos estapafúrdios ou as variações brilhantes com que ela the acaricie os olhos ou os ouvidos? Como é que os filhos serão amamentados, tratados, asseados, educados, dirigidos por esta brilhante boneca que não sabe senão coisas lindas e perfeitamente inúteis! (CARVALHO, 1891, p. 84-85)

Poucas páginas adiante, conclui:

Qual será, pois, a educação mais conveniente para uma rapariga? É aquela que a habilite a ser para o marido um auxílio e não um peso importuno; para os filhos um modelo a seguir, um guia seguro e adorado, e não apenas um objeto de platônica veneração e de respeito teórico.

O que o marido deseja após o trabalho cotidiano é uma casa aconchegada, confortável e cômoda, onde se sinta livre [...], que o seu jantar esteja bem feito, que seja macia e larga a sua poltrona ao pé do fogão, aceso em rubras labaredas, ou da janela, cheia de flores, que abre 
para um pequeno quintal; que ele possa confidenciar à sua esposa os seus cuidados e as suas preocupações, de modo que encontre nela conselho, arrimo e consolação; que os pequenos estejam muito sossegadinhos, e que não façam muita bulha, por terem aprendido com a mãe a respeitar, a venerar, com ternura tímida, o pai que chega à noite, cansado de haver lidado o dia inteiro para que eles vivam alegres, tranquilos, na fartura e no remanso da vida caseira. Para isto é que é preciso a mulher. (CARVALHO, 1891, p. 99-100)

Quando Christiana descobre que tanto os seus pais, como o pai de Júlio, trataram do acertar o casamento de ambos sem consultá-la antes, ocorre à primeira revelação do caráter e postura da moça:

CHRISTIANA. - (cruzando os braços) Muito bem, e eu?

FELISBERTO. - Tu! Não compreendo!

CHRISTIANA. - Quem os autorizou a disporem do que lhes não pertence?

ANTONIA. - (atrapalhada) Que dizes tu, menina?

ROMANA. - (à parte) Paris acabou de desorientá-la!

CHRISTIANA. - Eu sou maior, estou emancipada, e não admito que me desconsiderem. [...] (passeando agitadamente) Não me consultaram, não me ouviram, não trataram primeiro de averiguar se haveria ideias na minha cabeça, se haveria sentimentos no meu coração! Confundiram-me com as meninas ingênuas e idiotas, que os papás atiram, sem preâmbulo, para os braços do primeiro noivo rico! Encadearam arbitrariamente a minha liberdade, fizeram de mim um fantoche e sacrificaram-me odiosamente à velha tirania do quero, posso e mando! [...] Não, não sancionarei nunca um despotismo! A minha educação, o meu temperamento, o meu caráter, independente e altivo, insurgem-se contra a violência do forte exercida sobre o fraco! [...] (a Júlio) O meu coração pertencia-lhe, mas desde que adquiri a prova de que o senhor se prestou a ser instrumento da tirania paterna, odeio-o! (TORRESÃO, 1894, p. 34 et. seq.)

A fala de Christiana não poderia ser mais eloquente e libertadora. Rebelou-se contra o poder paterno de decidir o seu futuro, como se ela fosse um objeto desprovido de vontades e sonhos. Alberto, pouco adiante, tenta explicar ao conselheiro, pai de Júlio, o comportamento da sua sobrinha.

FELISBERTO. - Christiana é filha única, é voluntariosa, é caprichosa, aí tens tudo explicado. Contra os meus conselhos, foi criada ao sabor da sua fantasia. Os pais, que a adoram, deixaram-se seduzir pelo engodo de educá-la à moderna, dotando-a de todas as prendas decorativas que caracterizam as bonecas das salas, e esquecendo-se de incutir-lhe a única, indispensável na vida prática, - o bom senso.

CONSELHEIRO. - Oh! Homem, mas quantas meninas existem, tão prendadas como Christiana, e nem por isso, louvado Deus!, praticam os desatinos que censuramos em tua sobrinha! (TORRESÃO, 1894, p. 42) 
A família de Christiana culpa a educação moderna de que recebeu como causa elucidativa das suas atitudes e ideias. Entretanto, como aponta o conselheiro, porém sem chegar ao âmago da questão, não era a educação a fonte causadora de sua revolta, mas o suposto histerismo, termo que deve ser entendido aqui como o fato de Christiana possuir um pensamento completamente divergente sobre o papel da mulher na sociedade. Isso fica evidente na fala de Pedro, quando este tenta dissuadir Alberto da sua relação com a protagonista: "Volte para sua mulher e agradeça-a a Deus. É uma rapariga honesta, boa esposa, boa mãe, não é histérica, e a prova é que aceita, sem revolta, a posição subalterna de gata borralheira, a que você a condenou" (TORRESÃO, 1894, p. 50, grifo nosso).

Gabriela é outra personagem que irá crescer em importância ao longo da peça e emancipar-se de algumas ideias. No princípio é a gata borralheira que cuida com zelo da casa e do filho. Após o interesse manifesto do marido pela altiva Christiana, ressente-se da sua posição subalterna e busca aperfeiçoar-se. Alberto, conversando com o amigo Pedro, comenta a transformação da esposa com grande espanto e preocupação pelas dívidas adquiridas nas compras de livros e vestidos: "Imagine que, nestas alturas, a Gabriela abriu mão do governo da casa, fez-se coquette e voltou-se à leitura da biblioteca que você aí vê. (indica-lhe os livros)" (TORRESÃO, 1894, p. 85).

Em uma bela discussão entre esposa e marido no terceiro ato, encontramos:

ALBERTO. - (alto, com surdo mau bumor) Mas tu, antigamente, não saías, não lias, nem sequer pegavas em um jornal!...

GABRIELA. - (irônica) Mudei. Preciso instruir-me, civilizar-me. Comecei pelo corpo, que entreguei à modista... [...] Acabei pelo espírito, que dediquei à leitura.

ALBERTO. - (perdendo a paciência) Dedique-se à leitura dos róis, dediquese ao governo da casa, dedique-se à criação do seu filho!

GABRIELA. - [...] Perdão, tudo isso é reles, é ordinário, é supinamente burguês... Foi o senhor que o disse!

ALBERTO. - [...] (furioso) A senhora está a mangar comigo? Ensinaramlhe isso em Tavira?...

GABRIELA. - Em Tavira tinham-me ensinado que a missão de uma mulher casada resumia-se em olhar pela sua casa, pelo seu marido e pelos seus filhos...

ALBERTO. - (irritado, cru₹ando os bracos) E então?

GABRIELA. - (voltando-se para Alberto) O senhor encarregou-se de convencer-me do contrário. (assentando-se, com dissimulada indiferença). Os meus cuidados, o meu zelo, a minha dedicação conjugal, produziram-lhe o efeito de um vomitório. Comparou-me com as divindades das salas, que o senhor frequenta, e achou-me boçal... Faltava-me chic, faltava-me instrução, faltava-me a linha, dizia o senhor; tratei de adquiri-las (TORRESÃO, 1894, p. 88 et. seq.). 
Gabriela, nas falas finais da peça, diz ter obtido sua emancipação por meio do estudo e do aprendizado. Enquanto esta personagem conformava-se ao papel social que lhe era imposto de esposa, mãe e dona de casa, ela era conveniente a Alberto, seu marido, pois se mostrava útil, servil, submissa, dependente, nula. Quando Gabriela passa a revoltarse com o comportamento infiel do marido, ela torna-se, paulatinamente, a esposa imperfeita, incrivelmente incômoda, inflexível e insubordinada.

A peça teve uma fria recepção - tal qual $A$ burguesa - e a crítica teatral assinada por Vasco Magriço no Diário Ilustrado, nos traz algumas explicações:

A comédia é um delicado trabalho, bem ordenada, lógica no seu entrecho, e por vezes vazada naquele primoroso estilo que a autora sabe fazer, como poucos os que mourejam em letras no nosso país. Tem situações magníficas, cenas de fino espírito, contrastes de boa moral. Mas... é comédia para um teatro que nós não temos e para uma espécie de público que nós não possuímos. Falta-lhe a graça, o picante, a viveza, a pochade, o extraordinário, etc,. etc., Sobre o desempenho devemos especializar Beatriz e Soller, que nos seus... duetos de excentricidades e paradoxos, sabem perfeitamente sublinhar as situações. O papel de Beatriz fica sendo, pela maleabilidade do desempenho, um dos mais importantes do seu repertório. O público aplaudiu muito o beneficiado e mais atores, bem como a autora, que agradeceu de um camarote de onde assistia ao espetáculo (MAGRIÇO, 1891, p. 3).

Ambas as peças apresentaram ao público da época textos precursores, com feitios naturalistas e com temas sociais arraigadamente polêmicos. A incompreensão e o repúdio às mudanças exigidas por estas personagens femininas em cena podem elucidar as carreiras curtas de ambas as peças nos palcos e explicar o fato delas terem caído completamente no esquecimento da crítica literária.

\section{Apontamentos finais}

Apesar da existente diferença de nove anos entre as duas peças, os textos de ambas complementam-se, dialogam entre si. Guiomar Torresão assiste à peça de Gervásio Lobato, fica responsável por escrever-lhe a crítica teatral e, anos depois, apresenta ao público um original que tem, em seu cerne, questionamentos profundos sobre a educação feminina e o destino das mulheres dentro da sociedade portuguesa oitocentista finissecular, questionamentos que perpassaram as falas impetuosas e convictas de D. Leonor.

Não obstante, estes dois autores foram e permanecem marginalizados pelo cânone literário, tornando-se premente reavaliá-los criticamente. Em 1975, escrevia Osório Mateus 
que "se há setor da nossa história cultural onde é urgente uma revisão crítica global, esse setor é exatamente o da chamada história literária" (MATEUS, 1975, p. 36).

Talvez, quando esta revisão for feita, outras tantas personagens como Leonor, Christiana e Gabriela recuperem as suas vozes há tanto tempo silenciadas.

\section{Bibliografia}

ALMEIDA, Fialho de. Guiomar Torresão. In: ALMANACH das Senhoras para 1900. Lisboa: Parceria António Maria Pereira, 1899, p. 3-10.

BASTOS, António de Sousa. Diccionario do theatro portugués. Lisboa: Imprensa Libanio da Silva, 1908.

CÂMARA, João da. Crônica Ocidental. O Ocidente, $21^{\circ}$ ano, Lisboa, v. XXI, n. 714, p. 241 242, 30 de outubro de 1898.

CARVALHO, Maria Amália Vaz de. Cartas a uma noiva. 8 ed. Lisboa: Livraria Fluminense, 1891.

CHAGAS, PINHEIRO. Prólogo in LOBATO, Gervásio. A comédia de Lisboa. 2 ed. Porto: Livraria Chardon, 1911, p. III-XXV.

CORDEIRO, Luciano. Uma estreia. In CORDEIRO, Luciano. Estros e palcos. Lisboa: Typographia Universal, 1874, p. 117-123.

COSTA, Antonio. A mulher em Portugal. Lisboa: Livraria Férin, 1893.

CRUZ, Duarte Ivo. História do teatro português. Lisboa: Editorial Verbo, 2001.

EÇA DE QUEIROZ, José Maria. As meninas da Geração Nova em Lisboa e a Educação Contemporânea in MÓNICA, Maria Filomena (Coord.). As Farpas - Crónica mensal da política, das letras e dos costumes. Parede (Portugal): Princípia, 2004, p. 412-429.

EDFELDT, Chatarina. Uma bistória na História: representações da autoria feminina na História da Literatura Portuguesa do século XX. Montijo: Câmara Municipal de Montijo, 2006.

ESTATÍSTICA de Portugal. População: censo no $1^{\circ}$ de janeiro. 1878. Lisboa: Imprensa Nacional, 1881.

GARRETT, Almeida. Da educação. Livro primeiro: da educação doméstica ou paternal. Londres: Sustence e Stretch, 1829.

MAGRIÇO, Vasco. Primeiras representações - A Educação Moderna. O Diário Ilustrado, $20^{\circ}$ ano, Lisboa, n.6461, p. 3, 29 de março de 1891. 
MATEUS, Osório. Um ofício em centenário. Colóquio/Letras, Lisboa, n. 28, p. 35-38, Novembro de 1975.

LOBATO, Gervásio. A Burgueza: comédia original em 1 acto. Lisboa: Arnaldo Bordalo, 1912.

REBELLO, Luiz Francisco. O teatro naturalista e neo-romântico (1870-1910). Lisboa: Instituto de Cultura Portuguesa, 1978.

SEABRA, António Luís de. O Código Civil Português: aprovado por carta de lei de $1^{\circ}$ de julho de 1867. 11 ed. Coimbra: Imprensa da Universidade, 1933.

SERRÃO, Joel. Estrutura social, ideologias e sistema de ensino (séculos XIX e XX). In

SILVA, Innocencio Francisco. Diccionario Bibliographico Portuguez. Lisboa: Imprensa Nacional, 1884, p. 138. (Tomo $11^{\circ}$ )

TORRESÃO, Guiomar. Educação moderna: comédia original em três actos antecedida de uma conversa preambular. Lisboa: José Bastos, 1894. 